\title{
LITERASI MEDIA PROMOSI UMKM PKK RW O17 BABADAN BANGUNTAPAN, KAB BANTUL, DI YOGYAKARTA
}

\author{
Dewi Novianti', Siti fatonah ${ }^{2}$ \\ ${ }^{12}$ UPN "VETERAN" YOGYAKARTA \\ ${ }^{1}$ E-mail address dewi.novianti@upnyk.ac.id; ${ }^{2} \mathrm{E}$-mail address siti.fatonah@upnyk.ac.id
}

\begin{abstract}
The covid-19 pandemic outbreak has made the economy experience a decline. Economic activity is increasingly uncertain. This is also experienced by housewives RW17 Babadan, Banguntapan, Bantul Regency. Family Welfare Education women help the family economy with culinary businesses. They established micro, small and medium enterprises. The first problem is that these housewives experience difficulties in selling, due to their limited movement to offer their culinary works to consumers. Second, the understanding of media literacy in using social media as a new media is still lacking and thirdly, the understanding and ability to make messages is minimal through social media. Community service methods are discussion, focuse group discussion, socialization, and media literacy training. The solution to this problem is to hold training and mentoring on understanding media literacy in carrying out sales promotion activities. In addition, by holding skills training in documenting culinary products and in packaging messages through social media. The conclusion is that community empowerment by providing promotional media literacy makes them understand the benefits of using modern communication tools and new media. In the end, they were able to take advantage of smartphones to sell their products.
\end{abstract}

Keywords: Promotion Media Literacy, The Covid-19 pandemic

\begin{abstract}
Abstrak
Wabah pandemi covid-19 membuat perekonomian mengalami penurunan. Kegiatan perekonomian semakin tidak pasti. Hal ini dialami pula oleh IbuIbu Rumah Tangga RW17 Babadan, Banguntapan, Kabupaten Bantul. IbuIbu PKK membantu ekonomi keluarga dengan usaha kuliner. Mereka mendirikan Usaha mikro kecil dan menengah (UMKM). Permasalahan pertama adalah Ibu-Ibu Rumah tangga tersebut mengalami kesulitan dalam penjualan, karena terbatasnya gerak untuk menawarkan hasil karya kuliner mereka kepada konsumen. Kedua pemahaman literasi media dalam menggunakan media social sebagai media baru masih kurang dan ke tiga pemahaman dan kemampuan dalam membuat pesan yang minim melalui media sosial. Metode pengabdian masyarakat adalah diskusi, focuse group
\end{abstract}


discussion, sosialisasi, dan pelatihan literasi media. Solusi dari permasalahan tersebut adalah diadakan pelatihan dan pendampingan tentang pemahaman literasi media dalam melakukan kegiatan promosi penjualan. Selain itu dengan mengadakan pelatihan ketrampilan dalam mendokumentasikan produk kuliner serta dalam mengemas pesan melalui media social. Kesimpulannya adalah Pemberdayaan masyarakat dengan memberikan literasi media promosi menjadikan mereka paham akan manfaat dalam menggunakan alat komunikasi modern dan media baru. Pada akhirnya mereka mampu memanfaat smartphone untuk menjual produk-produk mereka.

Kata Kunci: Literasi media promosi, pandemi Covid-19

\section{PENDAHULUAN}

Usaha Mikro, Kecil dan Menengah (UMKM) mampu menopang sektor perekonomian rakyat kecil menengah. Di berbagai daerah sudah digalakkan UMKM diberbagai sektor, seperti kuliner, pertanian, peternakan, elektronik, furniture, bidang jasa, dan lain-lain. UMKM terbagi menjadi 3 jenis usaha, yaitu usaha mikro, usaha kecil, dan usaha menengah. Bila mengacu pada Undang-Undang nomor 20 tahun 2008, pembagian antara usaha mikro, usaha kecil, dan usaha menengah didasarkan pada kepemilikan aset dan omset. Usaha mikro adalah usaha produktif yang dilakukan oleh perseorangan maupun badan usaha sesuai dengan kriteria mikro. Bila mengacu pada undangundang maka kriteria usaha mikro adalah asetnya maksimal Rp5o juta dan omsetnya maksimal Rp3oo juta. Selanjutnya adalah usaha kecil. Usaha ini adalah usaha produktif yang didirikan oleh perorangan atau badan usaha. Dan bukan anak usaha atau cabang dari perusahaan-perusahaan besar. Usaha kecil memiliki kriteria aset antara Rp 50 juta hingga Rp50o juta dan omsetnya berkisar Rp3oo juta sampai Rp2,5 milliar. Terakhir adalah usaha menengah. Ini adalah usaha ekonomi produktif yang didirikan oleh perseorangan atau badan usaha. Bukan merupakan anak usaha ataupun cabang dari perusahaan besar. Usaha menengah memiliki kriteria jumlah aset berkisar Rp50o juta sampai Rp10 milliar dan omset berkisar Rp2,5 milliar hingga Rp50 milliar (https://qazwa.id/blog/umkm/).

Seringkali orang memandang UMKM dengan sebelah mata, namun jenis bisnis yang satu ini adalah yang paling menjadi harapan Negara Indonesia. Pada tahun 1997 dimana terjadi krisis moneter yang membuat banyak perusahaan besar tumbang. 
UMKM tetap bertahan dan bahkan menjadi penopang perekonomian saat itu.

UMKM di Kabupaten Bantul merupakan salah satu sektor perekonomian Pemerintah Daerah Bantul yang diharapkan mampu meningkatkan kesejahteraan masyarakat di lapisan menengah ke bawah, mengingat usaha tersebut memiliki visi yang sejalan dengan program pemerintah untuk mengurangi angka pengangguran masyarakat melalui pembukaan lapangan kerja baru.

Pemkab Bantul mendata ulang jumlah pelaku usaha mikro, kecil, dan menengah (UMKM). Dari hasil pendataan sementara, jumlah UMKM di Bantul ada sekitar 48.00o dan hanya 24.00o yang sudah ada data by name di tiap kecamatan. Jumlah ini lebih sedikit dibanding hasil pendataan badan Pusat Statistik (BPS) yang menyebut ada 121.00o UMKM di Bumi Projotamansari (https://jogjapolitan.harianjogja.com/re $\mathrm{ad} / 2020 / 02 / 17 / 511 / 1032068 /$ jumlahumkm-bantul-menyusut). Jumlah yang tidak sedikit ini merupakan asset bagi Pemkab Bantul untuk mengembangkan perekonomian rakyat. Namun sayangnya dengan merebaknya penyebaran virus corona atau Covid-19 sangat berdampak bagi para pelaku usaha, khususnya Usaha Mikro, Kecil dan
Menengah (UMKM). Banyak dari UMKM yang menagalami penurunan atau bahkan kerugian. Sejak Pemerintah Daerah Kabupaten Bantul mengeluarkan Surat Edaran Nomor : 440/01560 tentang penutupan sementara obyek wisata dalam rangka mencegah penularan infeksi Covid-19, yang dilanjutkan perpanjangan penutupan obyek wisata terhitung 01 hingga 31 April 2020 melalui Surat Edaran Nomor: 440/01615 berakibat transaksi jual beli mengalami penurunan yang sangat signifikan. Sebagai contoh Sentra Kerajinan Manding Karena selama ini mayoritas pembeli di Gerai Sentra Kerajinan Manding adalah wisatawan luar daerah yang menyempatkan berkunjung untuk membeli barang sebagai oleh-oleh. https://www.krjogja.com/beritalokal/diy/bantul/diterpa-covid-19umkm-di-bantul-mencoba-bertahan/2/

Tidak hanya pada sentra Manding, UMKM lainnyapun merasakan dampak dari wabah Covid-1. Diantaranya adalah UMKM Ibu-Ibu PKK RW 17 Babadan, Banguntapan, Bantul. Selama ini UMKM Ibu-Ibu PKK RW 17 Babadan, Banguntapan, Bantul dirasa cukup membantu perekonomian keluarga. Adapun usaha yang mereka lakukan adalah dibidang kuliner. Jenis- 
jenis kuliner yang diproduksi sepert; kue kering, angkringan, tahu bakso, aneka snack dan camilan, nasi box, Basreng, Ayam Kriwil, Es Susu Coki, Peyek Kentang, Teri, Bayam, kering tempe, dan tempe kremes. Cukup beragam usaha yang diproduksi oleh UMKM Ibu-Ibu PKK RW 17 Babadan, Banguntapan, Bantul. Omset mereka terbilang masih sangat kecil, terlihat pada table berikut:

Tabel 1.1 Jenis Usaha dan Omset

UMKM Ibu-Ibu PKK RW 17

Babadan, Banguntapan, Bantul

\begin{tabular}{|c|c|c|c|}
\hline No & Nama & $\begin{array}{c}\text { Jenis } \\
\text { Usaha }\end{array}$ & $\begin{array}{c}\text { Omset } \\
\text { Perbulan } \\
\text { Rp }\end{array}$ \\
\hline 1 & $\begin{array}{c}\text { Nia } \\
\text { Kurniati }\end{array}$ & $\begin{array}{c}\text { Kue } \\
\text { Kering }\end{array}$ & $\begin{array}{c}500.000- \\
750.000\end{array}$ \\
\hline 2 & $\begin{array}{c}\text { Sri } \\
\text { Yatini }\end{array}$ & $\begin{array}{c}\text { Snack } \\
\text { Dan Nasi } \\
\text { Box }\end{array}$ & 500.000 \\
\hline 3 & $\begin{array}{l}\text { Ainun } \\
\text { Irvani }\end{array}$ & $\begin{array}{c}\text { Angkring } \\
\text { an }\end{array}$ & 900.000 \\
\hline 4 & $\begin{array}{c}\text { Noorma } \\
\text { wati }\end{array}$ & $\begin{array}{l}\text { Tahu } \\
\text { Bakso }\end{array}$ & $\begin{array}{c}\text { 10.000.000 } \\
\text { (omset } \\
\text { kotor) }\end{array}$ \\
\hline 5 & $\begin{array}{c}\text { Zuni } \\
\text { Nuryant } \\
\text { o }\end{array}$ & $\begin{array}{c}\text { Snack,Na } \\
\text { si } \\
\text { Box,Anek } \\
\text { a } \\
\text { Camilan }\end{array}$ & 2.000 .000 \\
\hline 6 & Astuti & Jajan & 1.200 .000 \\
\hline
\end{tabular}

\begin{tabular}{|c|c|c|c|}
\hline & $\begin{array}{c}\text { Widaya } \\
\text { ni }\end{array}$ & Pasar & \\
\hline 7 & $\begin{array}{c}\text { Karniya } \\
\text { tun }\end{array}$ & $\begin{array}{l}\text { Warung } \\
\text { Makan }\end{array}$ & 1.000 .000 \\
\hline 8 & $\begin{array}{c}\text { Atik } \\
\text { Daniswa } \\
\text { ri }\end{array}$ & $\begin{array}{c}\text { Basreng, } \\
\text { Ayam } \\
\text { Kriwil,Es } \\
\text { Susu } \\
\text { Coki,Keri } \\
\text { ng } \\
\text { Kacang }\end{array}$ & 750.000 \\
\hline 9 & Gunadi & $\begin{array}{c}\text { Peyek } \\
\text { Kacang,T } \\
\text { eri,Kedel } \\
\text { ai,Bayam, } \\
\text { Kacang } \\
\text { Hijau }\end{array}$ & 400.000 \\
\hline 10 & $\begin{array}{c}\text { Sri } \\
\text { Hatun }\end{array}$ & Pecel Lele & 800.000 \\
\hline 11 & $\begin{array}{c}\text { Dwiriwa } \\
\text { nti }\end{array}$ & $\begin{array}{c}\text { Snack } \\
\text { Box N } \\
\text { Katering } \\
\text { Tk }\end{array}$ & $\begin{array}{c}1.000 .000- \\
1.500 .000\end{array}$ \\
\hline
\end{tabular}

Sumber : UMKM Ibu-Ibu PKK RW 17 Babadan, Banguntapan, Bantul, 2020

Kecilnya omset perbulan disebabkan kurang gencarnya aktivitas komunikasi pemasaran atau promosi yang dilakukan. Ibu-Ibu PKK tersebut hanya menunggu bola saja. Di samping itu, cakupan wilayah pemasaran mereka sangat sempit hanya di seputar tempat 
tinggal mereka saja. Ibu-Ibu pelaku UMKM ini masih tradisional dalam mempromosikan hasil usaha mereka. Apalagi setelah wabah Covid-19 ini muncul, penjualan semakin menurun. Keterbatasan UMKM Ibu-Ibu PKK RW 17 Babadan, Banguntapan, Bantul dalam memasarkan produk ini dikarenakan minimnya pengetahuan mengenai media promosi digital yang sedang marak saat ini. Media Promosi beragam, bisa melalui media massa konvensional seperti Majalah, Koran, Tabloid, Radio, dan Televisi. Media promosi dengan media massa membutuhkan biaya yang tidak sedikit. Di era digital saat ini media promosi semakin mudah hanya dengan menggunakan media social saja secara individu ibu-ibu PKK pelaku UMKM bisa melakukan aktivitas promosi penjualan. Padahal jika mereka sudah melek akan media digital, maka mereka dengan mudah bisa memasarkan hasil usaha kulinernya walaupun di tengan wabah Covid-19 ini.

Literasi media digital tidak hanya bagi remaja, pelajar, atau ibu-ibu rumah tangga saja yg memantau anakanak dan keluarganya dalam berinteraksi dengan media. Para pelaku UMKM pun butuh literasi media digital. Literasi media digital di sini dalam artian untuk membantu UMKM Ibu-Ibu
PKK RW 17 Babadan, Banguntapan, Bantul dalam mempromosikan produksi usahanya agar area pasarnya menjadi lebih luas lagi dan lebih mudah. Media promosi yang bisa digunakan beragam, seperti media social Face Book, Instagram, line, whatshap, youtube. Diharapkan dapat membantu meningkatkan produktivitas UMKM Ibu-Ibu PKK RW 17 Babadan, Banguntapan, Bantul. Muara akhirnya adalah membantu meningkatkan kesejahteraan keluarga.

Permasalahan yang dihadapi adalah Kondisi ekonomi UMKM Ibu-Ibu PKK RW 17 Babadan, Banguntapan, Bantul yang cenderung masih rendah sangat rentan terhadap berbagai permasalahan sosial. Kondisi ini juga berdampak pada kualitas lingkungan hidup dan kesehatan masyarakat.

UMKM Ibu-Ibu PKK RW 17 Babadan, Banguntapan, Bantul berlokasi di desa Babadan, Banguntapan Bantul. Ketika gempa pada saat terjadi gempa pada tanggal 27 juli 2006, wilayah ini termasuk yang terkena dampak yang cukup parah yang mengakibatkan perlambatan perkembangan ekonomi dan pendidikan. Saat ini wabah Covid-19 melanda dunia, tak terkecuali Indonesi dan khususnya Bantul. Sejak Pemerintah Daerah Kabupaten Bantul mengeluarkan Surat 
Edaran Nomor : 440/01560 tentang penutupan sementara obyek wisata dalam rangka mencegah penularan infeksi Covid-19, yang dilanjutkan perpanjangan penutupan obyek wisata terhitung 01 hingga 31 April 2020 melalui Surat Edaran Nomor: 440/01615 berakibat transaksi jual beli mengalami penurunan yang sangat signifikan.

Mayoritas jenis usaha UMKM Ibu-Ibu PKK RW 17 Babadan, Banguntapan, Bantul adalah kuliner atau makanan. Seperti yang sudah disampaikan pada analisis situasi di atas bahwa, usaha UMKM PKK RW 17 cukup beragam, hanya saja omset mereka yang masih sangat kecil.

Secara spesifik permasalahan yang dihadapi oleh mitra dapat dipetakan sebagai berikut:

1. Kurangnya

komunikasi pemasaran atau promosi yang dilakukan oleh UMKM Ibu-Ibu PKK RW 17 Babadan, Banguntapan, Bantul.

2. Ketidaktahuan mengenai media komunikasi pemasaran yang efektif untuk peningkatan penjualan usaha

3. Cakupan wilayah pemasaran masih sangat kecil, yakni hanya di seputar tempat tinggal mereka saja.
4. Persaingan wisata kuliner saat ini sangat tinggi, sehingga dibutuhkan pengetahuan komunikasi pemasaran dengan menggunakan media digital

5. Dunia sedang dilanda wabah Covid-19 yang berdampak luas termasuk menurunnya perekonomian rakyat. Diberlakukannya lock dawn oleh pemerintah dan warga sendiri, membuat ruang gerak UMKM Ibu-Ibu PKK RW 17 Babadan, Banguntapan, Bantul semakin sempit.

\section{METODE}

Melihat permasalahan yang ada, tim pelaksana kegiatan $\mathrm{PbM}$ bersama dengan masyarakat mitra akan melakukan kegiatan-kegiatan yang terarah pada mencerdaskan mitra dalam menggunakan media digital sebagai media komunikasi pemasaran UMKM Ibu-Ibu PKK RW 17 Babadan, Banguntapan, Bantul. Adapun soslusi yang ditawarkan secara garis besar adalah pendididkan literasi media Komunikasi Pemasaran melalui sosialisasi literasi media komunikasi pemasaran, pelatihan metode media komunikasi pemasaran yang tepat bagi UMKM Ibu-Ibu PKK RW 17 Babadan, Banguntapan, Bantul, DI Yogyakarta. 
Secara lebih rinci, pendekatan tersebut diuraikan dalam kegiatankegiatan di bawah ini.

1) Kegiatan sosialisasi dan motivasi pendidikan literasi media untuk menyadarkan masyarakat yang menjadi mitra pentingnya cerdas menggunakan media komunikasi pemasaran.

2) Focus Group Discussion (FGD) dengan mitra untuk menjaring pendapat dan memetakan pengalaman sehari-hari mitra dalam berinteraksi dengan media

3) Pemutaran acara-acara video youtube tentang promosi usaha-usaha kuliner yang berhasil sebagai motivasi membangkitkan semangat berwirausaha dan mempromosikan usaha bagi UMKM Ibu-Ibu PKK RW 17 Babadan, Banguntapan, Bantul.

4) Pelatihan metode literasi media komunikasi pemasaran untuk menambah pengetahuan, wawasan, dan mencerdaskan masyarakat yang menjadi mitra. Pelatihan dilakukan beberapa kali sampai kedua mitra menjadi cerdas dalam menggunakan media komunikasi pemasaran.

\section{Pelaksanaan Kegiatan}

Lokasi pengabdian di desa Babadan, Banguntapan, Kabupaten
Bnatul, Yogyakarta. Mitra berjumlah sebelas orang, semuanya ibu-ibu rumah tangga yang menjadi anggota PKK RW 17 Babadan, Banguntapan, Bantul, Di Yogyakarta. Kesebelas ibu-ibu ini memiliki usaha kecil seperti yang telah diuraikan di atas. Angka statistik UMKM Ibu-Ibu PKK RW 17 Babadan, Banguntapan, Bantul sebanyak 11 Orang dengan 11 usaha, dengan berbagai macam latar belakang pendidikan mulai dari SMA, MAN, sampai lulusan SD.

Waktu pelaksanaan bulan Juli 2020 di kediaman salah seorang Ibu pelaku UMKM.

\section{HASIL DAN PEMBAHASAN}

Perbaikan kualitas kehidupan selalu diperlukan, khususnya di bidang ekonomi. Pemberdayaan kaum perempuan sebagai pembantu ekonomi keluarga merupakan hal biasa dilakukan di masyarakat.

Pemberdayaan masyarakat pada dasarnya merupakan strategi perubahan sosial secara terencana yang ditujukan untuk mengatasi masalah atau memenuhi kebutuhan masyarakat. Dalam proses pemberdayaan, masyarakat mendapatkan pembelajaran agar dapat secara mandiri melakukan upaya-upaya perbaikan kualitas kehidupannya. Dengan demikian, proses tersebut harus dilaksanakan dengan 
adanya keterlibatan penuh masyarakat itu sendiri secara bertahap, terusmenerus, dan berkelanjutan (Wildan \& Sumarno, 2015).

Makna pemberdayaan menurut Jim Ife, yang berarti memberikan sumber daya, kesempatan, pengetahuan dan ketrampilan kepada warga untuk meningkatkan kemampuan mereka dalam menentukan masa depannya sendiri dan berpartisipasi dalam dan mempengaruhi kehidupan dari masyarakatnya (Jim Ife, 1995). Dalam kergiatan pengabdian masyarakat ini pemberdayaan dari sisi ekonomi dilakukan dengan memberikan pemahaman dan ketrampilan dalam memanfaatkan dan mengemas pesan promosi supaya masyarakat khususnya Ibu Ibu Rumah tangga RW Babadan.

Komunikasi merupakan proses penyampaian pesan dari komunikator kepada komunikan. Dalam proses tersebut terdapat unsur unsur komunikasi yaitu : komunikator, pesan, media komunikan dan dampak dari komunikasi. Beragamnya media saat ini menjadikan orang harus pandai memilih media yang tepat dan pesan yang menarik supaya tujuan dari komunikator tercapai. Artinya komunikasi dapat berjalan efektif. Salah satu media yang sekarang sedang marak adalah media baru. Menurut Denis McQuail (2011), dalam bukunya Teori Komunikasi Massa ciri utama dari media baru adalah adanya saling keterhubungan, aksesnya terhadap khalayak individu sebagai penerima maupun pengirim pesan, interaktivitasnya, kegunaan yang beragam sebagai karakter yang terbuka, dan sifatnya yang berada di mana-mana atau tidak bergantung pada lokasi.

Media inilah yang dimanfaatkan oleh Ibu Ibu Rumah tangga RW17 Babadan Banguntapan Bantul dalam mempromosikan produk produk usaha mereka. Perkembangan teknologi informasi di Negara Indonesia semakin meningkat dari hari ke hari. Hal ini sangat dipengaruhi oleh mudahnya masyarakat untuk memperoleh fasilitas internet yang efisien didukung dengan pola konsumtif masyarakat untuk selalu berlomba lomba memilki alat media komunikasi. Kebutuhan tersebut seolah tidak terkalahkan dengan kebutuhan pokok sebagian besar masyarakat Indonesia. Telephon seluler yang dulunya hanya dimilki oleh masyarakat ekonomi kalangan menengah ke atas sekarang bisa dikatakan siapapun orang bisa memilki hanpdphone dikarenakan harga sangat murah dan mudah dalam mendapatkannya serta kemudahan dalam mendapatkan akses dan fasilitas internet. Kalau dulu handpone hanya dimanfaatkan untuk bertelephone, 
namun sekarang dengan perkembangan dengan adanya ponsel pintar yang dapat dipergunakan untuk bermedia social dan kemudahan sarana internet menjadikan pergeseran manfaat. Ponsel pintar banyak dimanfaat untuk kegiatan bernedia social dan e-commerce. Hal ini menjadi peluang bagai UMKM atau para pengusaha tradisional untuk melakukan promosi produknya melalui media social. Salah satu UMKM yang ada adalah UMKM Ibu-Ibu PKK RW 17 Babadan, Banguntapan, Bantul. Tim pengabdian kepada Masyarakat berusaha membantu menyelesaikan permasalahan dengan melakukan kunjungan ke lokasi mitra. Pada kunjungan itu tim Pengabdian melakukan diskusi serta wawancara mendalam dengan beberapa Ibu ibu rumah tangga pelaku UMKM bersama pengurus dan sesepuh mitra. Hasil diskusi tersebut menemukan bahwa dimasa pandemi covid-19 ekonomi masyarakat di desa Babadan, Banguntapan, Bantul mengalami kelumpuhan. Karena banyak Kepala Keluarga atau pekerja warga Babadan yang dirumahkan atau mengalami Putus Hubungan Kerja (PHK). Sementara ibuibu yang biasanya berdagang keliling atau membuka warung terpaksa tidak bisa beroperasi disebabkan berkurangnya pembeli dan diberlakukannya lock dawn oleh warga sekitar yang tidak mengizinkan pedagang keliling untuk masuk ke lokasi perumahan dan sekitarnya. Akhirnya Ibu-Ibu rumah tangga yang biasanya berjualan makanan mencoba menawarkan melalui media social seadanya. Tim PbM menemukan bahwa kebutuhan mitra adalah pentingnya literasi media promosi dan pentingnya dalam membuat pesan media promosi supaya pesan tersampaikan dengan baik kepada konsumen, sehingga konsumen tertarik untuk membeli produk yang ditawarkan. Langkah-langkah solutif yang diberikan Tim PbM kepada mitra adalah sebagai berikut: pertama, Kegiatan yang dilakukan adalah dengan mengadakan kegiatan sharing melalui whatsApp group tentang konten-konten media promosi melalui media digital. Dengan demikian, mitra memilki pengalaman sehari - sehari dalam berinteraksi dengan media.

Langkah kedua, adalah melakukan Focus Group Discusions, dengan menghadirkan narasumber di bidang komunikasi pemasaran. Dari hasil FGD dirumuskan bahwa diperlukan pelatihan cara membuat pesan melalui dokumentasi produk dan pemilihan media pesan yang tepat yang diikuti oleh anggota mitra. Wabah Covid-19 menjadi 
cambuk bagi mitra untuk bisa lebih kreatif dalam berinovasi memproduksi produk dan menawarkannya ke konsumen. Mitra memproduksi berbagai macam kuliner seperti keripik tempe, tahu bakso, kering kentang, peyek dan masih banyak lagi aneka makanan, namun mereka masih perlu bimbingan untuk mempromosikannya.

Gambar 1.2. suasana pelatihan literasi media promosi

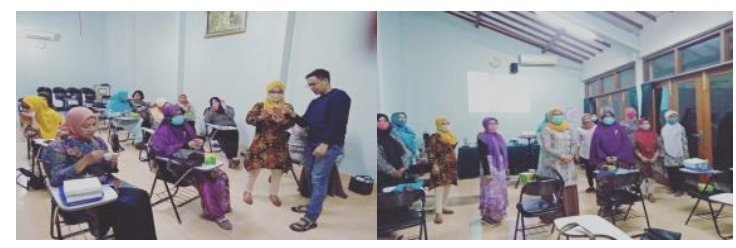

Sumber: Dokumentasi probadi, 2020

Langkah ke tiga, tim $\mathrm{PbM}$ mengadakan Pelatihan bagi UMKM IbuIbu PKK RW 17 Babadan, Banguntapan, Bantul bersama Tim Pelatih dan Narasumber. Pelatihan ini diikuti oleh 15 peserta Ibu Ibu Rumah Tangga pelaku UMKM. Ibu Kepala Desa turut serta dalam pelatihan tersebut sebagai wujud perhatian dan support kepada anggota masyarakatnya. Pelatihan diawali dengan memberikan motivasi kepada peserta untuk tetap bersemangat dalam menghadapi pandemic Covid-19. Selanjutnya, Tim PbM memberikan pelatihan kepada mitra tentang pendidikan literasi media promosi serta bagaimana mampu mengaplikasikan media promosi. Dilanjutkan dengan praktek dan membuat media promosi penjualan, memutarkan berbagai video para pengusaha UMKM yang berhasil dengan menggunakan media komunikasi pemasaran. Para peserta pelatihan semua mempraktekan dan mengirim karyanya melalui Whatsap group dan dievaluasi oleh tim sampai mereka mampu mebuat pesan dan dokumentasi melalui media social untuk mempromosikan produk-produk yang dijual.

Langkah keempat tim $\mathrm{PbM}$ melakukan pendampingan kepada mitra. Setelah melakukan pelatihan dan pendampingan ada perkembangan yang signifikan, dimana mitra sudah mempu membuat foto atau dokumentasi gambar-gambar usaha kuliner mereka yang kemudian di unggah di media social pribadi seperti Instagram, face book, dan grup WhatsApp. Penjualan kembali bergairah dengan mulai adanya pemesanan via on line. Omset penjulan secara perlahan mulai mengalami peningkatan. Yang terpenting adalah ibu-ibu PKK RW 17 Babadan, Bnguntapan, Bantul memiliki semangat untuk mengembangkan UMKM mereka.

Gambar.1.3. Foto dokumentasi Mitra Hasil pelatihan dan pendampingan 


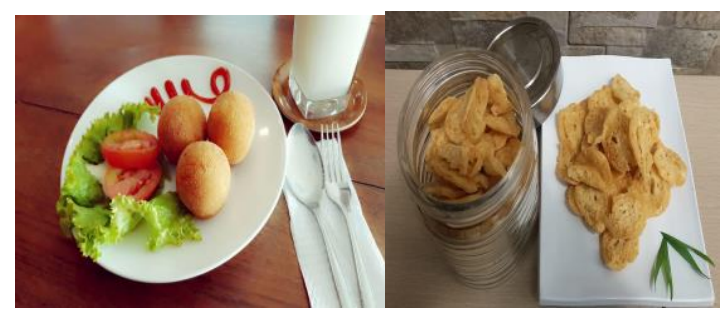

Sumber: Dokumentasi pribadi, 2020

\section{Penutup}

\section{Simpulan}

UMKM Ibu-Ibu PKK RW 17

Babadan, Banguntapan, Bantul memiliki motivasi yang tinggi untuk belajar memanfaatkan media social untuk melakukan promosi. Hal ini bisa dilihat dari hasil karya mereka setelah mengikuti pelatihan. Dari yang dulunya tidak paham dalam membuat pesan dan sekarang mereka sudah bisa membuat pesan documenter dan memilih media yang tepat untuk melakukan promosi. Pemberdayaan masyarakat dengan memberikan literasi media promosi menjadikan mereka paham akan manfaat dalam menggunakan alat komunikasi modern dan media baru. Penjualan online mulai dilakukan serta menunjukkan hasil. Secara perlahan pemesanan via on line mulia berdatangan, semangat membantu perekonomian keluarga kembali tumbuh seiring bertambahnya pengetahuan literasi media promosi.
Pengabdian serupa bisa dikembangkan di daerah-daerah lainnya yang memiliki UMKM perempuan. Pemberdayaan perempuan khususnya ibu-ibu rumah tangga perlu dibina supaya bisa membantu perekonomian keluarga.

\section{Ucapan terima kasih}

Tim PbM mengucapkan terima kasih kepada Lembaga Penelitian dan Pengabdian kepada Masyarakat Universitas Pembangunan Veteran Yogyakarta yang telah mendanai Pengabdian kepada Masyarakat. Ucapan terima kasih juga kami haturkan kepada UMKM PKK RW 17 Babadan, Banguntapan, Bantu, DI Yogyakarta yang telah bersedia menjadi Mitra.

\section{DAFTAR PUSTAKA}

Baran, Stanley and Dennis K Davis. 2000. Mass communication theory. Wadsworth: Canada

James, Potter W., 2005, Media Literacy, third edition. Sage Publication: New Delhi.

J Ife-1995, Community Development: Creating Community Alternatives, Vision Analysis and Practice. Australia: Longman,

Lister, M., Dovey, J., Giddings, S., et. al. (2009). New media: a critical introduction second edition. New York: Routledge.

McQuail, Denis. (2011). Teori komunikasi massa. Jakarta: Salemba Humanika.

\section{Saran}


Sasangka dan darmanto. 2010, Ketika Ibu Rumah Tangga Membaca televisi. Tifa :Yogyakarta

Soemandoyo, Priyo. ND. 2010, Wacana Gender dan Layar Televisi: Studi Perempuan dalam Pemberitaan Televisi. Ford Foundation dan LP3Y: Yogyakarta.

Sugiyono. 2014. Metode Penelitian Kuantitatif, Kualitatif, dan $R \& D$. Bandung: Alfabeta.

Wiratmojo, 2010, Ketika Ibu Rumah Tangga Membaca televisi. Tifa :Yogyakarta

Jurnal :

Saugi Wildan, Sumarno Sumarno, Jurnal Pendidikan dan Pemberdayaan Masyarakat Volume 2 - Nomor 2, November 2015, (226 - 238) hal 2

http://id.wikipedia.org/wiki/Literasi m edia, 14/03/2015

(https://qazwa.id/blog/umkm/Dendy Herdianto, 2020).

(https://jogjapolitan.harianjogja.com/re ad/2020/02/17/511/1032068/jumlahumkm-bantul-menyusut).

https://www.krjogja.com/beritalokal/diy/bantul/diterpa-covid-19umkm-di-bantul-mencoba-bertahan/2/ 